\title{
Introduction studies of Caucasian species of the genus Primula L. in the Polar-Alpine Botanical Garden and Institute
}

\author{
Nadezhda Trostenyuk $^{1 *}$, Ekaterina Sviatkovskaya ${ }^{1}$, and Natalia Saltan ${ }^{1}$ \\ ${ }^{1}$ Polar-Alpine Botanical Garden and Institute of KSC RAS, 184209 Apatity, Russia
}

\begin{abstract}
The results of introduction studies of 15 Caucasian species of the genus Primula L. (Primula abchasica, P. acaulis, P. algida, P. amoena, P. cordifolia, P. darialica, P. farinosa, P. juliae, $P$. komarovii, $P$. macrocalyx, $P$. pallasii, $P$. ruprechtii., $P$. saguramica, $P$. sibthorpii, $P$. woronowii) conducted in the Polar-Alpine Botanical Garden and Institute are presented. Currently, the institute's collection contains 8 species $(P$. acaulis, $P$. amoena, $P$. juliae, $P$. macrocalyx, $P$. pallasii, $P$. ruprechtii, $P$. saguramica, $P$. woronowii). Ecological and geographical analysis has shown that the species best adapted to the conditions of the Arctic are those that live in the alpine ( $P$. algida, P. amoena, P. cordifolia, $P$. juliae, $P$. pallasii, $P$. ruprechtii, $P$. sibthorpii - introduction coefficient $[\mathrm{IC}]=9.4)$ and subalpine zones of mountains $(P$. macrocalyx, $P$. acaulis $-\mathrm{IC}=8.2)$. While plants found in the broad-leaved forest zone are less adapted to the new living conditions ( $P$. komarovii, $P$. saguramica, $P$. woronowii $\mathrm{IC}=6.4$ ). The current research establishes that species of the genus Primula can serve as a source of plant assortments to replenish landscaping in cities in the Murmansk region. For this purpose two new decorative and sustainable species (P. macrocalyx и P. ruprechti) are recommended.
\end{abstract}

\section{Introduction}

The genus Primula, which comprises about 500 species distributed mainly in temperate zones and in the alpine belt of mountains, is a promising flower design for the cities of the Kola North. The centers of species diversity are located in the Himalayas, the mountains of Southwest China and Central Asia, the Caucasus and the Alps [1-3]. Representatives of the genus Primula are not recorded in the flora of the Murmansk region. Since 1934, the PolarAlpine Botanical Garden and Institute (PABGI) has been studying the effects of introducing species of the genus Primula, with 121 species of various ecological and geographical origins added to the collection nurseries. The most stable representatives (9 species) are included in the gardening assortment [4].

This study of the species of the genus Primula in our conditions is relevant, because its representatives are highly decorative and most of them are among the first to begin flowering in the spring. The aim of this work is to analyze the introduction tests of

* Corresponding author: tnn aprec@mail.ru 
Caucasian species of this genus to determine their viability in being introduced in the landscaping assortment for cities in the Kola region.

\section{Object and methods}

The objects of research are the Caucasian species of the genus Primula (P. abchasica Sosn., $P$. acaulis (L.) L., P. algida Adams, P. amoena Bieb., P. cordifolia Rupr., P. darialica Rupr., P. farinosa L., P. juliae Kusn, P. komarovii Losinsk., P. macrocalyx Bunge, $P$. pallasii Lehm., P. ruprechtii Kusn., P. saguramica Gavr., P. sibthorpii Hoffmanns., $P$. woronowii Losinsk.), introduced at different times by PABGI $[1,5]$. The research was conducted using the large-scale research facilities "Collections of living plants at the PolarAlpine Botanical Garden and Institute”, reg. No. 499394. The source material was obtained from the botanical gardens of Russia and foreign countries in the form of seeds or living plants, and was also collected in natural habitats during expeditions to the Caucasus, Altai and Georgia. Phenological observations were carried out according to standard methods [67]. To make up the introduction forecast, ecological-geographical analysis was used [8]. The ability of plants to bear fruit was adopted as an indicator of the success of the introduction. Survival points (SP) were given in accordance with the 12-point scale proposed by B.N. Golovkin [9].

The ratio of survival points for each species to the average score for the entire population of tested samples represents the introduction coefficient (IC), reflecting the introduction value of the group of plants under consideration. The higher the IC, the more important the corresponding group of plants is for the purposes of introduction.

\section{Results and Discussion}

The Polar-Alpine Botanical Garden and Institute, located in the center of the Khibiny massif, has been instrumental in introducing the Primula genus to the Kola North. The climate conditions of this region feature a relatively short growing season and almost annual frosts at the end of each summer month. The average monthly air temperature in the warm season is $10^{\circ}-14^{\circ} \mathrm{C}$. May 26 to July 18 comprises polar days at Khibin's latitude. Winter is frosty; the snow cover reaches $200 \mathrm{~cm}$ [10].

Experimental collection nurseries of perennial herbaceous plants are located in the forest belt of the northern taiga. Since 1934, 106 samples of 15 Caucasian species of the genus Primula have been tested here. The results of the analysis of the introduction, based on an assessment of the survival rate of plants recorded over an 88-year period, are given in Table 1. Seven of the species (Primula abchasica, P. algida, P. sibthorpii, P. cordifolia, P. komarovii, $P$. darialica, $P$. farinose $)$ have not yet been preserved in the PABGI collection for various reasons. Currently, there are 27 samples of eight species (P. acaulis, P. amoena, P. juliae, P. macrocalyx, P. pallasii, P. ruprechtii, P. saguramica, P. woronowii) in the nurseries.

In 1940, for the first time, an expedition from the Caucasus brought Primula acaulis to the institute in the form of wild plants. It is a perennial, rhizome stemless plant with a height of 5.0 to $8.0 \mathrm{~cm}$ and a flowering period of 15-20 days from the beginning of June. The single flowers are funnel-shaped, measuring $2.5-3.0 \mathrm{~cm}$ in diameter.

Primula amoena arrived in 1955 with cultivated seeds from St. Petersburg; it was included in the landscaping assortment in 1988 [11]. This plant grows up to $30 \mathrm{~cm}$ high. The flowers are bright purple-blue, with a diameter of $2.5-3.0 \mathrm{~cm}$ and a flowering period of 15-20 days from early June on. It is abundantly self-seeding, and its seeds ripen annually. 
Table 1. The results of the analysis introduction of species of the genus Primula on Kola peninsula.

\begin{tabular}{|c|c|c|c|c|c|}
\hline \multirow[b]{2}{*}{ Species } & \multirow[b]{2}{*}{$\begin{array}{l}\text { Years of } \\
\text { testing }\end{array}$} & \multicolumn{2}{|c|}{ Number of samples } & \multirow{2}{*}{$\begin{array}{c}\text { Final phase of } \\
\text { development }\end{array}$} & \multirow{2}{*}{$\begin{array}{l}\text { Survival points } \\
\text { (SP) }\end{array}$} \\
\hline & & Tested & $\begin{array}{c}\text { Available in } \\
2019\end{array}$ & & \\
\hline $\begin{array}{l}\text { Primula } \\
\text { abchasica }\end{array}$ & 1962-1964 & 1 & - & V & 2 \\
\hline P. acaulis & $1940-$ u. n. & 14 & 2 & $\mathrm{Fr}$ & 9.1 \\
\hline P. algida & $\begin{array}{c}1937- \\
1993\end{array}$ & 9 & - & $\mathrm{Fr}$ & 7.7 \\
\hline P. amoena & $1955-$ u. n. & 9 & 6 & $\mathrm{Fr}$ & 12 \\
\hline P. cordifolia & $\begin{array}{l}1971- \\
2001\end{array}$ & 2 & - & $\mathrm{Fr}$ & 10 \\
\hline P. darialica & $\begin{array}{c}1964- \\
1965\end{array}$ & 1 & - & $\mathrm{V}$ & 1 \\
\hline P. farinose & $\begin{array}{c}1964- \\
2002\end{array}$ & 3 & - & $\mathrm{V}$ & 1 \\
\hline P. juliae & $1963-$ u. n. & 5 & 1 & Fl & 9 \\
\hline P. komarovii & $\begin{array}{c}1964- \\
1977\end{array}$ & 2 & - & Fl & 6.5 \\
\hline P. macrocalyx & $1955-$ u. n. & 21 & 2 & $\mathrm{Fr}$ & 9.1 \\
\hline P.pallasii & $1934-$ u. n. & 23 & 9 & $\mathrm{Fr}$ & 11.4 \\
\hline P. ruprechtii & $1958-$ u. n. & 4 & 3 & $\mathrm{Fr}$ & 11 \\
\hline P. saguramica & $1966-$ u. n. & 3 & 3 & $\mathrm{Fr}$ & 11 \\
\hline P. sibthorpii & $\begin{array}{c}1939- \\
1955\end{array}$ & 2 & - & $\mathrm{Fr}$ & 10 \\
\hline P. woronowii & $1953-$ u. n. & 7 & 1 & $\mathrm{Fr}$ & 7.1 \\
\hline
\end{tabular}

Note: V-vegetation; B- bud formation, Fl - flowering; GF-green fetus; Fr -fruiting, u. n. - Until now «-» not available

Primula juliae was brought by cultivated plants from Riga (Latvia) in 1963 for testing in PABGI and was included in the landscaping assortment in 2010 [4]. The bush is a compact perennial 10-15 cm tall, growing into a continuous turf. The flowers are starshaped, raspberry-pink in the center with a yellow spot up to $3 \mathrm{~cm}$ in diameter. The flowering period extends from the end of June for 2 to 3 weeks, but the seeds do not ripen annually.

In 1955, Primula macrocalyx entered the institute for the first time with wild plants from Dushanbe. Currently, the collection has preserved plant specimens grown from wild seeds obtained from Yerevan (1974) and Leninogorsk (1976). The plant height is 30-35 $\mathrm{cm}$; the flowers are bright yellow, measuring $2.7-3.2 \mathrm{~cm}$ in diameter; and it blooms in midJune for 20 days.

Primula pallasii was brought to the institute in the form of wild plants from Altai in 1934. It is perennial, with a height of $25-30 \mathrm{~cm}$. The flowers are light yellow, measuring up to $2.5 \mathrm{~cm}$ in diameter, collected in 3-10 pieces in umbellate inflorescences. It blooms from early June for 20-25 days. Seeds ripen annually. In 1941, N.A. Avrorin this species was included in the landscaping assortment, but in the future, it was not mentioned in any version [12].

Primula ruprechtii has been tested in PABGI since 1958. It was first received via wild plants from Bakuriani, and repeated testing of this species has been done on wild plants from both Bakuriani (1971) and the Caucasus (1973). A perennial with a height of 15-20 $\mathrm{cm}$, its flowers are bright yellow with a diameter of $2.0-2.4 \mathrm{~cm}$. It flowers from mid-June for up to 20 days and its seeds ripen annually.

Primula saguramica first entered the Botanical Garden with wild plants from Nalchik in 1966. Subsequently, seeds of local reproduction of the first (1985) and second (1990) 
generations were used to grow plants. Currently, three samples of this species have been preserved in collection nurseries. The plant height is $18-25 \mathrm{~cm}$, and yellow flowers with a diameter of 2.0-2.5 cm appear from the second decade of June for 20 days. Seeds ripen annually in late August to early September.

For introduction tests, Primula woronowii was brought from Nalchik by wild plants in 1953. Currently, the collection contains plants grown from seeds obtained from the Main Botanical Garden in Moscow in 1964. The height of the plants is 5.0-7.5 cm. The flowers are single, pale lilac with a yellow center $3.0-3.6 \mathrm{~cm}$ in diameter. The flowering period extends 20 days from late May to early June; seeds do not ripen annually.

The success of plant introduction is determined by correctly choosing areas of their natural habitat. Ecological and geographical analysis is the method used to ascertain whether the correct habitat has been chosen. We performed an ecological and geographical analysis for 12 species (100 samples) of the genus Primula. Species and samples tested in collection nurseries for less than 2 years were excluded from the analysis. The average survival point for species of the genus Primula is 1.1. The studied species were divided into 4 ecological and geographical groups, which were then allocated according to the latitudinal and altitudinal limits of natural distribution (Table 2).

Table 2. The survival rate of different ecological and geographical groups of the genus Primula in the conditions of the Kola Peninsula.

\begin{tabular}{|c|c|c|c|}
\hline Ecological and geographical groups & Виды & $\begin{array}{l}\mathrm{SP}, \\
\text { mean }\end{array}$ & $\mathrm{IC}$ \\
\hline $\begin{array}{l}\text { obligate oreophytes (mountain plants) } \\
\text { entering the alpine zone of mountain }\end{array}$ & $\begin{array}{c}\text { P. algida, } P \text {. amoena, } P \text {. cordifolia, } P . \\
\text { juliae, } P \text {. pallasii, } P \text {. ruprechtii, } P . \\
\text { sibthorpii }\end{array}$ & 10.3 & 9.4 \\
\hline $\begin{array}{l}\text { plants growing only in the taiga zone and } \\
\text { reaching the mountains of the subalpine } \\
\text { zone }\end{array}$ & P. macrocalyx & 9.1 & 8.2 \\
\hline $\begin{array}{l}\text { plants growing from taiga to broad-leaved } \\
\text { forest zone entering the alpine belt of } \\
\text { mountains }\end{array}$ & P. acaulis & 9.1 & 8.2 \\
\hline $\begin{array}{l}\text { plants found only in broad-leaved forest } \\
\text { zone }\end{array}$ & $\begin{array}{l}\text { P. komarovii } \\
\text { P. saguramica } \\
\text { P. woronowii }\end{array}$ & 7.1 & 6.4 \\
\hline
\end{tabular}

\section{Conclusion}

Results of the introduction studies of Caucasian species of the genus Primula, demonstrated that the collection nurseries of PABGI can successfully preserve and grow representatives of this genus. Ecological and geographical analysis showed that the species best adapted to the conditions of the Arctic are those living in the alpine ( $P$. algida, P. amoena, $P$. cordifolia, $P$. juliae, $P$. pallasii, $P$. ruprechtii, $P$. sibthorpii $-\mathrm{IC}=9.4)$ and the subalpine belt of mountains ( $P$. macrocalyx, $P$. acaulis - IC=8.2). These species manage, in a short growing season, to go through the entire development cycle, bloom annually, and give mature seeds. Plants found in the broad-leaved forest zone ( $P$. komarovii, $P$. saguramica, $P$. woronowii - IC $=6.4$ ) are the worst adapted to the new habitat conditions. For further scientific and economic use of plants of the genus Primula in the Kola Subarctic, it is necessary to attract species that live in nature in the alpine and subalpine zones of mountains. Plants entering the high-altitude zones of the mountains have an IC higher than the plants of the plains of the corresponding natural zones.

Long-term experience in introducing this species has shown the genus Primula can increase the species diversity of the landscaping assortment for cities and towns of the 
Murmansk region. They are valuable for their durability, winter hardiness, unpretentiousness and relative resistance to diseases and pests. For the flower decoration of the polar cities, in addition to the already well-used species of the genus Primula (Primula amoena and Primula juliae), we can recommend Primula macrocalyx and P. ruprechti, which are stable in our conditions and which are highly decorative, with golden yellow flowers that make up for the bright colors that northern nature lacks at the beginning of summer.

\section{References}

1. A. A. Fedorov, Flora of the USSR 18 (Nauka, Leningrad, 1952)

2. E. S. Aksenov, N. A. Aksenova, The decorative floriculture for lovers and professionals: herbaceous plants (Moscow, 2001)

3. H. Chi-ming, S. Kelso, Flora of China. 15, 39-189 (1996)

4. O. B. Gontar, V. K. Zhirov, L. A. Kazakov, E. A. Svyatkovskaya, N.N. Trostenyuk, Green building in Murmansk region (Publ. Kola Science Center of the Russian Academy of Sciences, Apatity, 2010)

5. A. A. Grossgeym, Flora the Caucasus 7 (Nauka, Leningrad, 1967)

6. I. N. Beydeman, Method of phenological observations in geobotanical research (Moscow, Leningrad, 1954)

7. Method of phenological observations in the Botanical gardens of the USSR. Bull. of GBS. 113, 3-8 (1979)

8. N. A. Avrorin, Migration of plants to the Polar North. Ecological and geographical analysis (Nauka, Moscow, Leningrad, 1956)

9. B. N. Golovkin, Migration of herbaceous perennials to the Polar North (Nauka, Leningrad, 1973)

10. A. P. Semko, Flora and vegetation of the Murmansk region (Leningrad, 1972)

11. G. N. Andreev, L. A. Kazakov, O. A. Korabelnikova, L. I. Lozhevskaya, T. I. Churkina, Agrotechnics decorative plants in the North (Apatity, 1988)

12. N. A. Avrorin, How to green cities and towns of the Murmansk region and Northern districts of the Karelo-Finnish SSR (Kirovsk, 1941) 